\title{
Plasma Pulse Technology to Control Zebra Mussel Biofouling
}

BACKGROUND AND PURPOSE: A plasma sparker has been developed by Sparktec Environmental Inc. to control settlement of zebra and quagga mussels. Plasma pulse technology is a physical, nonchemical, nonthermal process for introducing energy directly into an aqueous solution. This patented system is made up of three separate components, a power supply to control the power management, a capacitor storage bank to store the required energy, and a submersible assembly where this energy is released to the water. When the plasma sparker is activated, electrical energy stored by capacitors is released between two submerged electrodes in microseconds. A plasma channel is formed because of this high current/high voltage electrical discharge. The discharge process consists of at least three primary events, an intense shockwave, a steam bubble which may lead to a supercritical water phase where oxidation of organic substrates will occur, and ultraviolet light. The technology is currently in use in several utilities and industries in Canada and the United States. These experiments, most of which are now completed, are designed to show what mechanisms are being employed to control zebra mussel biofouling in pipelines.

Mechanisms being evaluated are: (i) indirect control through continuous application of pulsed power to limit biofilm biomass and composition; (ii) direct control through continuous application of pulsed power to (a) kill the zebra mussels, (b) detach mussels already settled, (c) prevent settlement of new recruits and reattachment of translocators; and (iii) control by application of pulsed power for short durations to sustain permanent damage to shells or weaken the mussels sufficiently that they eventually die.

\section{Materials and Methods}

Field Experiments. A field experiment was carried out in the forebay at Nanticoke Thermal Generating Station (NTGS), Lake Erie, to determine if continuous application of pulsed power can: (1) limit biofilm biomass and composition; (2) kill adult zebra mussels, (3) detach mussels already settled, and (4) prevent settlement of new recruits and reattachment of translocators. Six PVC pipes $4 \mathrm{~m}$ long by $30 \mathrm{~cm}$ inside diameter with a wall thickness of $4.5 \mathrm{~mm}$ were suspended about $2 \mathrm{~m}$ below the water surface by aircraft cables from three floating docks. Each pipe had fifteen 10.2-cm-diam holes cut into it, with five along the bottom and five along each side. The discs that were removed were to be used as coupons to determine the amount of zebra mussel settlement that occurred inside the pipes during the summer. In order to reinsert the disc into its hole and hold it in place, a larger disc (12.6-cm-diam) was cut from a spare pipe to act as a flange. The coupon was attached to the flange by a bolt. The flange, with its coupon, was held in place on the pipe by means of two No. 10 Robertson screws.

In order to determine if plasma pulse technology was affecting biofilm formation in the pipes, glass slides were attached to three of the fifteen coupons in each pipe. The glass slides were attached to each coupon by means of two slots cut into a $5.1-\mathrm{cm}$-diam polyethylene cylinder. The three coupons 
with the glass slides were randomly placed, such that each row of five coupons had one with glass slides and four lacking glass slides; the latter were used to determine settlement rates of zebra mussels.

A 1.27-cm rope mesh was attached to the intake end of each pipe to prevent fish or objects from entering the pipes. A 1.27-cm-thick acrylic plate was glued and fastened to close the outlet end of each pipe. For an outlet, a 2.54-cm-diam nipple was threaded into place at the top of the pipe and behind the opening for the submersible pulser (a unit that contained the electrode that emits the pressure pulse waves. A rectangular hole, about $15.2 \mathrm{~cm}$ by $20.3 \mathrm{~cm}$, was also cut out of the top and bottom of three pipes for inserting a sleeve to accept the submersible pulser. The sleeve was cemented in place to prevent water from leaking out of the spaces around the sleeve. The sleeve allowed easy removal of the submersible pulser for replacing electrodes and making any necessary adjustments in electrode configurations.

Three floating docks were used for the field experiments. One pipe with a submersible pulser was suspended from one side of a dock and one pipe without the pulser (i.e., the control) was suspended from the other side of a dock using a buoy at each end of the pipe. Water was pulled through each pair of pipes (one control and one with a submersible pulser) by a 1/2-hp jet pump. The water velocity through each pipe was estimated to be about $0.37 \mathrm{~m} / \mathrm{min}$, which was deemed optimal for zebra mussel settlement.

The pipes were lowered into position (3-m depth) on August 7, 1998 by means of two winches, one at each end of the pipe; then power was applied to the submersibles. A pulse of 5,000 V was released with a duration of $40 \mu$-sec at 35-sec intervals. The site was visited at 3- to 4-day intervals to ensure that the plasma pulsers and pumps were operating efficiently.

The coupons were removed on September 29, October 29, and November 24, 1998. For each sampling event, power to all submersibles was cut off and one pipe at a time was lifted out of the water. One coupon with glass slides and three without glass slides were selected at random and removed from each pipe. The coupons were replaced by spare coupons that were made from a spare pipe. The total time that pipes were out of the water was always less than $15 \mathrm{~min}$.

During removal of coupons on November 24, it was noted that settlement was occurring mainly on the top half of the inside of the pipe. Many of the coupons removed (random selection) in October and November were from the bottom half of the pipe, where about $1-2 \mathrm{~cm}$ of mud had settled and probably prevented mussel settlement. Coupons were sampled again at the end of the experiment. After all pipes were removed from the water, fifteen 10.2-cm-diam coupons were removed from the top and sides of each pipe using a hole saw. The average number of mussels was determined for the 15 coupons and the number per square meter was determined by multiplying the average number by 123.4 (number of coupons $/ \mathrm{m}^{2}$ ). The length (in millimeters) of 10 mussels (or all mussels present if less than 10) was determined for each coupon with an ocular micrometer at 80X magnification, and then the average length per pipe was calculated.

The total number of mussels on each coupon was determined using a dissecting microscope at $30 \mathrm{X}$ magnification. The lengths of 10 mussels (or fewer if less than 10 occurred), selected at random, were determined using an ocular micrometer at $80 \mathrm{X}$ magnification. 
On November 10, rocks with attached zebra mussels were placed in each pipe to determine if plasma pulse technology could kill adult mussels before terminating the experiment at the end of November. The rocks, with attached zebra mussels, were collected from Hamilton Harbour on November 8, 1998. Rocks with 45-50 mussels were used; if more than 50 mussels were attached, they were removed until 50 mussels remained. Three rocks with attached mussels were placed in the posterior third of each pipe. After the pipes were pulled from the water in November, the number of mussels remaining on each rock was determined. Due to a power failure at Nanticoke on November 20, 1998, the mussels were exposed to plasma pulses for only 10 days.

Laboratory Experiments. Experiments were also carried out to determine if continuous application of pulsed power in a laboratory setting can: (1) limit biofilm biomass formation; (2) kill adult zebra mussels; and (3) detach adult mussels from rocks. Laboratory experiments were also done to determine if short-term (5 weeks) application of pulsed power can control zebra mussel biofouling by destroying the shell integrity of adult zebra mussels that would eventually lead to the death of affected mussels.

Six fiberglass tanks, each $2 \mathrm{~m}$ long, $50 \mathrm{~cm}$ wide, and $50 \mathrm{~cm}$ deep were used for all the laboratory experiments. Approximately $600 \mathrm{~L}$ of water from Lake Ontario was placed in each tank for the experiment. Rocks with zebra mussels were taken from Hamilton Harbour about a week before the experiment. It was assumed that the water in the tanks had enough food to maintain the zebra mussels over the 5-week experiment. Water levels were topped off at about 2-week intervals with fresh water from Lake Ontario.

A 2-m length of PVC pipe, similar to those used in the field experiments, was placed in each tank to focus most of the energy from the submersible electrodes on the zebra mussels that were placed inside the pipe. A "Little Giant" submersible pump was placed behind the submersible pulser to draw water from the far end of the pipe toward the electrodes. An air stone was placed at the opposite end of the pipe to aerate the water before it was drawn toward the submersible electrode. Dissolved oxygen values were maintained above 85 percent in all tanks, as determined by the modified Winkler method in a Hach Kit (model OX-2P). The plasma pulsers were set to deliver a pressure wave $40 \mu / \mathrm{sec}$ in duration, at 35- to 40 -sec intervals after $5000 \mathrm{~V}$ had been collected in the capacitors.

The three control tanks had the same setup as the three test (plasma pulse) tanks, except the plasma pulse electrodes were not present. Also, because the steel electrodes gave off iron particulates upon each spark, steel rods of the same material as the electrodes were placed in the control tanks to emulate the effect of the electrodes.

Five rocks, each with ten adult mussels, were placed inside the pipe of each tank. The five rocks were placed near the farthest (from the submersible electrodes) end of the pipe and near the aerating stones. Mussel mortality (as determined by gaping valves that failed to close upon gentle prodding) was recorded on a rock, selected at random, at weekly intervals for 5 weeks. After the number of dead mussels was recorded, the surviving mussels were placed in aquaria with Lake Ontario water. One aquarium was devoted to a tank so that each aquarium (six total) had rocks with surviving mussels from only one tank. Mortality of mussels on rocks in the aquaria was recorded at weekly intervals. All dead mussels were saved for examination of shell integrity. 
The effect of plasma pulses on biofilm formation was determined using five 5-cm-wide by $12.7-\mathrm{cm}-$ long acrylic slides placed in a CPVC rack. Four racks of five slides were placed on the inside and bottom of each pipe within each tank. Two slides were removed weekly to examine the rate of biofilm formation.

Shell integrity was determined using scanning electron microscopy (SEM) of the inner shell surface of 15 dead shells from each of the treatment and control tanks. The length of cracks in the shells was used to assess shell integrity in "pulsed shells" and control shells. Both living and dead shells were examined to ensure that the cracking was due to plasma pulses and not to normal processes.

\section{RESULTS AND DISCUSSION}

Field Experiments. Treatment Pipe No. 3 was closest to the trashracks and water flow often forced the pipe to lie, or butt against, the trashrack. Treatment Pipe No. 1 was the only pipe that had no failures recorded during the 3-month trial (see Appendix I).

Due to high water currents in the forebay, the submersibles were not always firing in an upright position. However, this problem does not exist in industrial settings. Nevertheless, new air-actuated submersibles have been developed to address and eliminate this kind of problem and will also resolve most of the other service problems described in Appendix I.

Table 1 summarizes the amount of settlement that occurred in the pulsed pipes (pipes receiving plasma pulses) and control pipes on September 29, October 29, and November 24. The data show that there was approximately 29 times more settlement in the control pipes (3-month mean $\left.=10,537 / \mathrm{m}^{2}\right)$ than in the pulsed pipes $\left(3\right.$-month mean $\left.=367 / \mathrm{m}^{2}\right)$. While there was significantly lower ( $\mathrm{P}<0.05$, student t-test) settlement in the pipes treated with plasma pulses than in the control pipes, the numbers of mussels attached to the inside walls of the pipe declined over time in both the treatment and control pipes. The data suggest that some of the settled mussels had detached over the 3-month period. The coupons for removal were randomly selected at each sampling event so as not to bias the effect of location on the pipe.

However, over time, mud had settled on the bottom of the pipe and smothered the mussels that had attached (on the bottom) in August and September. Hence, coupons from the bottom of the pipe lacked, or had low numbers of, settled mussels.

Because the bottom of the pipes had mud that appeared to affect the settlement rates or survival of mussels, 15 coupons were cut from the top ( 5 total) and both sides (5 from the left and 5 from the right side) of the pipes to determine settlement rates in these locations. The results (Table 2) show nearly two orders of magnitude (i.e. 100X) difference between the control and pulsed pipes, with an average of 50,690 mussels $/ \mathrm{m}^{2}$ in the control pipes and 584 mussels $/ \mathrm{m}^{2}$ in the pulsed pipes. These results show more convincingly than Table 1 data that plasma pulse technology is effective as a proactive control strategy (i.e., it significantly reduces settlement of new recruits of zebra mussels). 


\begin{tabular}{|c|c|c|c|c|c|c|c|c|c|}
\hline \multicolumn{10}{|c|}{$\begin{array}{l}\text { Table } 1 \\
\text { Number of Zebra Mussels Settled }\left(/ \mathrm{m}^{2}\right) \text { on Coupons Removed from Pipes on } \\
\text { September } 29, \text { October } 29 \text {, and November } 24,1998^{1}\end{array}$} \\
\hline \multirow[t]{2}{*}{ Pipe } & \multicolumn{3}{|c|}{36066} & \multicolumn{3}{|c|}{36096} & \multicolumn{3}{|c|}{36122} \\
\hline & $\# / \mathrm{m}^{2}$ & Length & S.E. & $\# / \mathrm{m}^{2}$ & Length & S.E. & $\# / \mathrm{m}^{2}$ & Length & S.E. \\
\hline Control 1 & 1388 & 3.4 & 0.32 & 1172 & 3.9 & 0.79 & 617 & 5.7 & 1.21 \\
\hline Control 2 & 8391 & 3.5 & 0.45 & 432 & 3.1 & 0.71 & 154 & 5 & 0.71 \\
\hline Control 3 & 11023 & 3.1 & 0.34 & 7939 & 4.5 & 0.53 & 494 & 8 & 0.73 \\
\hline Control Mean & ${ }^{*} 6,934^{1}$ & 3.33 & 0.37 & $* 3,181^{1}$ & 3.8 & 0.68 & $? ?$ & 6.2 & 0.88 \\
\hline Treatment 1 & 0 & ----- & ----- & 31 & ----- & ----- & 0 & ----- & ----- \\
\hline Treatment 2 & 288 & 1.6 & 0.11 & 0 & ----- & ----- & 0 & ----- & ----- \\
\hline Treatment 3 & 165 & 2.1 & 0.21 & 554 & 3.57 & 0.51 & 0 & ----- & ----- \\
\hline Treatment Mean & 1511 & 1.9 & 0.16 & 2161 & 3.57 & 0.51 & 0 & ----- & ----- \\
\hline
\end{tabular}

\begin{tabular}{|c|c|c|}
\hline $\begin{array}{l}\text { Table } 2 \\
\text { Numbers }\left(/ \mathrm{m}^{2}\right) \text { and Si }\end{array}$ & Mussels Settling & alf of Inside of Pipes ${ }^{1}$ \\
\hline Pipe & No. of Mussels $\left(/ \mathrm{m}^{2}\right)$ & Mean Length $(\mathrm{mm}) \pm \mathrm{S} . \mathrm{E}$. \\
\hline Control 1 & 57126 & $7.3 \pm 0.73$ \\
\hline Control 2 & 53284 & $7.4 \pm 0.69$ \\
\hline Control 3 & 41660 & $6.1 \pm 0.56$ \\
\hline Control Mean & 50690 & $6.9 \pm 0.66$ \\
\hline Treatment 1 & 1744 & $6.2 \pm 0.21$ \\
\hline Treatment 2 & 8 & $5.4 \pm 0.81$ \\
\hline Treatment 3 & 0 & ---- \\
\hline Treatment Mean & 584 & $5.8 \pm 0.51$ \\
\hline $\begin{array}{l}{ }^{1} \text { Numbers based on } 15 \text { cou } \\
\text { number is significantly large } \\
\text { shell length. }\end{array}$ & $\begin{array}{l}\text { ach pipe, } 5 \text { from the } t \\
\text { the treatment mean }\end{array}$ & $\begin{array}{l}\text { each side. The control me } \\
m^{2} \text {. See text for explanatio }\end{array}$ \\
\hline
\end{tabular}

To determine if plasma pulse pressure waves have any effect on the growth in shell length of settled mussels, only new recruits were measured. Translocating adults were not included in this analysis. Analyses of the length data in Table 1 showed a significant effect $(\mathrm{P}<0.05$, student t-test) on growth of recruits in September but only a moderate effect $(\mathrm{P}<0.15)$ in October (no settlement was found 
on the treatment coupons in November). However, the data included mussels on the bottoms of the pipes where the layer of mud may also have had an effect on growth of recruits. Table 2 gives the results of measurements made only on mussels settled on the tops and sides of the pipes.

The data in Table 2 show a significant difference $(\mathrm{P}<0.05, \mathrm{~N}=45$ for control, $\mathrm{N}=11$ for treatment pipes) in mean shell length of new recruits after 3 months exposure, with a mean of $6.9 \mathrm{~mm}$ shell length in the control pipes and $5.8 \mathrm{~mm}$ in the treatment pipes. Hence, it appears that plasma pulse technology also affects the growth of recruits on pipelines.

Translocating adults were found in all pipes, including the treatment pipes, in the analyses at the end of the experiment. When the translocations occurred within each pipe is unknown, but while replacing the jet pump for treatment No. 3 on October 20 (see Appendix I), some adults were observed within the pipe.

The power supply of the Nanticoke Thermal Generating Station was also interrupted for about a week, beginning November 20, and hence, the experiment was terminated on November 24, 1998. The mussels attached to the three rocks that were placed in each pipe were exposed to the plasma pulse pressure waves for only 10 days. Nevertheless, data in Table 3 indicate that plasma pulse technology was beginning to have an effect on survival/attachment ability of adult mussels on the rocks. The loss of adults from the rocks may be due to either mortality or simply to detachment. The mortality/detachment of adults from rocks in control pipes was $6 / 400$ mussels (1.5 percent) and in treatment pipes it was $41 / 420=9.8$ percent. Using an adult mortality rate of 9.8 percent in 10 days obtained in the field trial, one can expect 100-percent mortality to be achieved in about 14.6 weeks in a 4-m length of pipe.

\begin{tabular}{||l|c|c|c|c|c|c||}
\hline \hline \multirow{2}{*}{$\begin{array}{l}\text { Table 3 } \\
\text { Numbers of Mussels Remaining on Three Rocks Placed in Pipes for 1.5 Weeks }\end{array}$} \\
\hline \hline \multirow{3}{*}{\begin{tabular}{l} 
Pipe \\
\hline \hline Control 1
\end{tabular}} & \multicolumn{3}{c||}{ Number Alive at Start } & \multicolumn{3}{c||}{ Number Alive at End } \\
\cline { 2 - 8 } & Rock 1 & Rock 2 & Rock 3 & Rock 1 & Rock 2 & Rock 3 \\
\hline Control 2 & 50 & 50 & 50 & 50 & 50 & 46 \\
\hline Control 3 & 50 & Missing & 50 & 50 & Missing & 50 \\
\hline Treatment 1 & 50 & 50 & 50 & 50 & 49 & 49 \\
\hline Treatment 2 & 50 & 50 & 50 & 48 & 42 & 49 \\
\hline Treatment 3 & 55 & 40 & 45 & 32 & 36 & 42 \\
\hline
\end{tabular}

The laboratory tests showed greater adult mortality than the field trial. Table 4 shows that after five weeks of plasma pulse pressure waves, there was an average adult mortality of 54 percent in the treatment tanks, compared to 14-percent adult mortality in the control tanks. The results suggest that about 9.3 weeks would be required to achieve 100-percent mortality of adults in the laboratory experiment. In the field trial, 9.8-percent mortality was obtained in 10 days, or about 34.3-percent 


\begin{tabular}{|l|c|l|c||}
\hline \hline \multicolumn{4}{|l||}{$\begin{array}{l}\text { Table } \mathbf{4} \\
\text { Mean Percent Mortality of Adult Zebra Mussels in Six Laboratory Test Tanks (three for } \\
\text { plasma pulse treatment and three for controls) }\end{array}$} \\
\hline \hline \multicolumn{1}{|c|}{ Test Tank } & Percent Mortality & \multicolumn{1}{|c||}{ Test Tank } & Percent Mortality \\
\hline \hline Control 1 & 18.2 & Treatment 1 & 58.2 \\
\hline Control 2 & 10 & Treatment 2 & 50.4 \\
\hline Control 3 & 12.6 & Treatment 3 & 52.6 \\
\hline Control Mean & $\mathbf{1 3 . 6}$ & Treatment Mean & 53.7 \\
\hline
\end{tabular}

mortality after 5 weeks. However, the pipes in the laboratory trials were only $2 \mathrm{~m}$ long, which may explain the higher mortality rate. However, the experiment needs to be repeated over a longer period of time in order to more accurately predict the amount of time needed to obtain 100-percent mortality in short pipelines.

To determine if destruction of shell integrity is a mechanism of killing adults, dead treatment and control mussel shells from the laboratory experiments were examined using scanning electron microscopy (SEM). Preliminary studies (i.e. based on SEM analyses of five dead shells from treatment tanks and five dead shells from control tanks) suggest that the plasma pulse pressure waves do affect the integrity of the shell, with approximately 75 percent more cracks in the shells from pulsed tanks than in shells from control tanks. However, one shell in the control group had significantly more cracking than the other four, which had none. This may be due to an error in mixing one shell from the pulsed group into the control group. Ten more shells from each of the treatment and control groups remain to be examined.

The amount of biofilm accumulating on test coupons was evaluated by placing test coupons in each of the test tanks and removing them at the end of the 5-week trial. Material on each coupon $\left(65-\mathrm{cm}^{2}\right.$ surface area) was scraped into pre-weighed glass-fibre filter papers. The material was dried at $60{ }^{\circ} \mathrm{C}$, weighed, then ashed at $550{ }^{\circ} \mathrm{C}$ to burn off the organic matter (the biofilm). The results (Table 5) show that plasma pulse technology also is effective at reducing biofilm formation, with an average of $10.15 \mathrm{mg}$ of organic material on coupons from the control pipes and $1.26 \mathrm{mg}$ of organic material on coupons from the pulsed pipes.

Similar analyses were made on coupons removed from pipes in the field trials. Five coupons, each 10.2-cm diameter, were cut from the walls of each of the control and pulsed pipes. All mussels were removed, including the byssal threads, taking care not to remove any biofilm or other attached organisms (e.g. algae, insect cases, sponges). The remaining material was scraped off onto filter papers, dried at $60^{\circ} \mathrm{C}$, and weighed. Table 6 confirms the observations, with a significantly greater ( $\mathrm{P}<0.001)$ mean biomass of biofilm on control pipes $(8.99 \mathrm{mg} /$ coupon $)$ than on treatment (pulsed) pipes (0.64 mg/coupon) (Figure 1). 


\begin{tabular}{|c|c|c|c|}
\hline \multicolumn{4}{|c|}{$\begin{array}{l}\text { Table } 5 \\
\text { Results of Laboratory Analyses of the Biomass of Biofilm and Other Materials That } \\
\text { Accumulated on Three Test Coupons }{ }^{1} \text { in Pipes in Control Tanks and Pipes in Tanks } \\
\text { Receiving Plasma Pulse Pressure Waves }\end{array}$} \\
\hline Coupon Source & $\begin{array}{c}\text { Total Biomass }(\mathrm{mg}) \\
\text { (organic and inorganic)/ } \\
\text { Coupon }\end{array}$ & $\begin{array}{c}\text { Biomass }(\mathrm{mg}) \text { After } \\
\text { Ashing at } 550^{\circ} \mathrm{C} \\
\text { (= inorganic weight) }\end{array}$ & $\begin{array}{l}\text { Loss in Weight After } \\
\text { Ashing at } 550^{\circ} \mathrm{C} \\
(\approx \text { biofilm biomass }) \\
\end{array}$ \\
\hline Control 1 & 10.451 & 0.59 & 9.861 \\
\hline Control 2 & 9.602 & 0.52 & 9.082 \\
\hline Control 3 & 12.116 & 0.616 & 11.5 \\
\hline Control Mean & 10.723 & 0.575 & 10.148 \\
\hline Treatment 1 & 2.434 & 1.324 & 1.11 \\
\hline Treatment 2 & 2.862 & 1.952 & 0.91 \\
\hline Treatment 3 & 6.846 & 5.086 & 1.76 \\
\hline Treatment Mean & 4.047 & 2.787 & 1.26 \\
\hline
\end{tabular}

\begin{tabular}{|c|c|c|}
\hline \multicolumn{3}{|c|}{$\begin{array}{l}\text { Table } 6 \\
\text { Observations on Microscope Slides Placed in Pipes in Nanticoke Forebay }{ }^{1}\end{array}$} \\
\hline Coupon Codes & Sediment Load & Comments \\
\hline C $1-1$ & +++ & \\
\hline C $1-4$ & ++ & Zebra mussel on one of two slides \\
\hline C 2-2 & +++ & \\
\hline C $2-4$ & ++++ & $\begin{array}{l}\text { Heavy sediment on slides; a branching (algal?) growth and some } \\
\text { zebra mussel shells were encrusted on the slide holder }\end{array}$ \\
\hline C 3-1 & +++ & Two zebra mussels on one slide \\
\hline C 3-3 & ++ & Heavy sediment (silt) on the holder; three zebras on one slide \\
\hline T 1-3 & & Slides lost in pipe \\
\hline T 2-2 & + & $\begin{array}{l}\text { Clean coupon, thin silt layer on slide, some organic material and } \\
\text { protozoa, but not as developed as other samples }\end{array}$ \\
\hline T $3-4$ & ++++ & High load of desmids seen microscopically \\
\hline
\end{tabular}




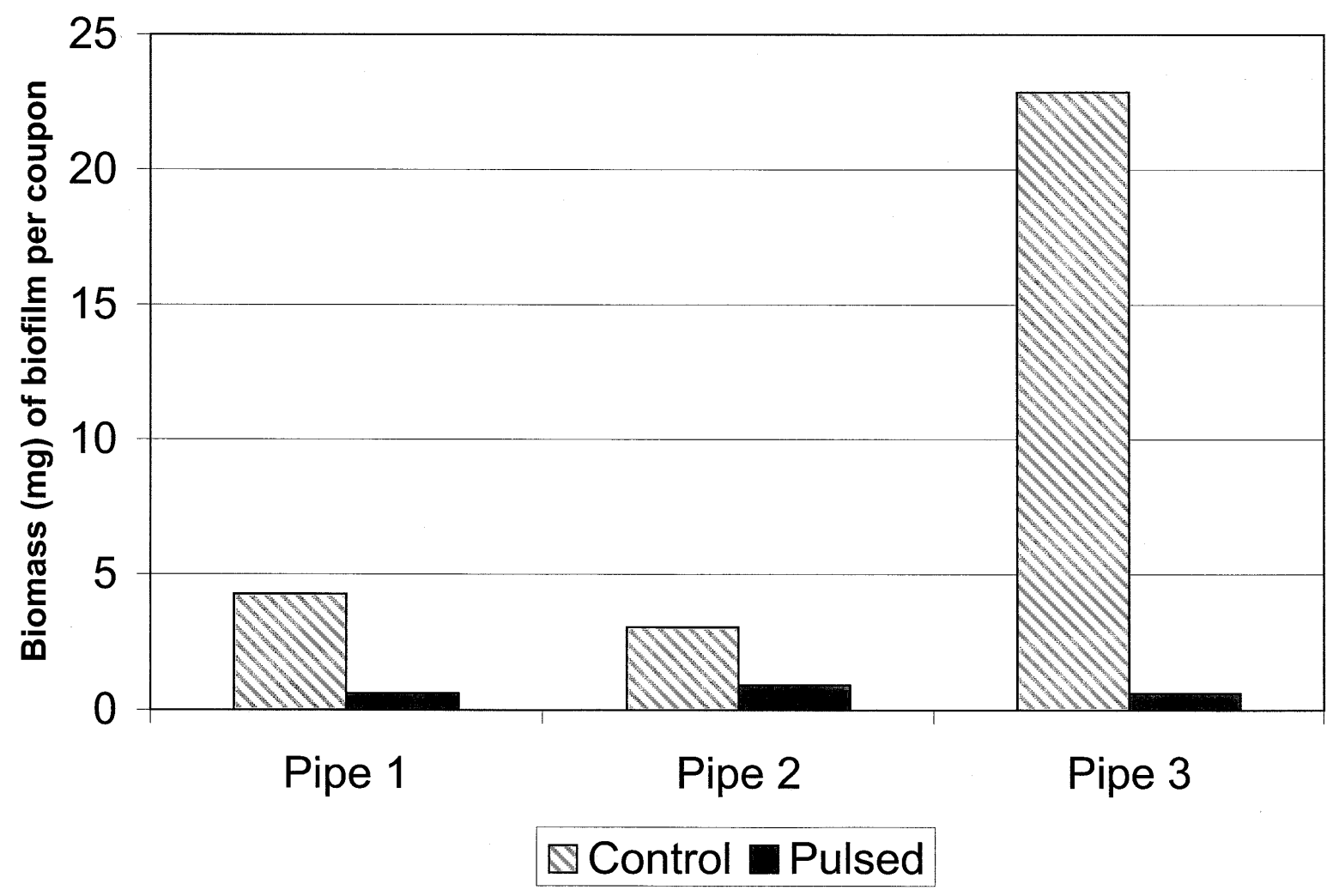

Figure 1. Mean biomass (mg) of biofilm on pulsed and control coupons

Standard glass microscope slides mounted in plastic holders and fixed to a heavy plastic curved disc cut from experimental pipes were also used to evaluate the effect of plasma pulses on biofilm formation. The microbiology coupons were placed within the flow pipes in the laboratory simulation (two runs) and the Nanticoke lake run (two sets of samples). Upon removal, the microscope slides were kept wet and examined with a phase-contrast microscope for microorganisms. The coupons from the lake pipes were heavily sedimented and, for many of these, the gross appearance of the slides and holders could only be scored qualitatively (Tables 6 and 7).

The microscope slides and holders removed on October 30, 1998 were coated with substantial amounts of grey-green scum and silt deposits, which made microscopy difficult because of the thickness of material on the slides. Even very clean coupons had dense films, indicating that biofilms were able to develop in some of the test slides and most of the control slides (Table 6). In general, all of the control slides had a heavy film of organic debris, with ciliate and flagellate protozoa, desmids, and a background of bacteria evident. Qualitatively, the rank order of debris on the slide holders was: $\mathrm{C} 2-4>\mathrm{C} 2-2, \mathrm{C} 3-3>\mathrm{C} 1-4>\mathrm{T} 1-3>\mathrm{C} 3-1>\mathrm{T} 3-4>\mathrm{C} 1-1>\mathrm{T} 22$. However, the major distinction between sample groups seemed to be in gross levels of silting, rather than biological loads. The heavy silt load, in combination with the organic materials on surfaces, made it difficult and not very useful to discern shifts in the make-up of the biofilm. Even if a change was induced in the population of indigenous bacteria that have been reported to affect zebra mussels, such metabolic products are likely to be inactivated or bound up by the silt and organic load associated with practical pipe situations. 


\begin{tabular}{||l|l||}
\hline \multicolumn{2}{|l||}{\begin{tabular}{l||} 
Table 7 \\
Observations on Microscope Slides Placed in Pipes in Nanticoke Forebay
\end{tabular}} \\
\hline \hline Coupon Code & Comments \\
\hline \hline C $1-2$ & Heavy clay layer; zebra mussels and crustaceans present \\
\hline C $1-5$ & Heavy fibrous clay coating; many zebra mussels (100+) \\
\hline C 2-1 & Clean of most clay but many large zebra mussels \\
\hline C 2-3 & Light clay coat; smaller zebra mussels \\
\hline C 3-3 & Heavy clay layer, many mussels on coupon holder and slides \\
\hline C 3-5 & Heavy clay layer, many mussels on coupon holder and slides \\
\hline T 1-1 & Heavy clay deposit on it (10 mm+), some mussels 2-3 mm long \\
\hline T 1-2 & Light clay deposit \\
\hline T 1-3 & Light clay deposit; no zebras, groups of "shrimp" \\
\hline T 2-1 & Light silt layer; $11-12$ zebras on plastic holder \\
\hline T 2-3 & Clay in chunks \\
\hline T 3-3 & Light clay coat, crustaceans present \\
\hline T 3-5 & Light clay coat, a few crustaceans \\
\hline \hline 1 Samples were removed October $30,1999$. C = control pipe, T = pulsed pipe; first number is pipe number, \\
second number is position relative to submersible, 1 being closest, 5 being farthest away. \\
\hline
\end{tabular}

The last studies to be done were on the physical attributes of plasma technology. The attributes of the SEI plasma sparker examined included the voltage, electrode gap size, and the discharge cycle. The duration of the pulse was not varied, and ranged between 150-300 microseconds ( $\mu$ sec). The study was performed by Dr. Charles Robert Welch of the Shock and Vibration Information Analysis Center (SAVIAC), U.S. Army Engineer Research and Development Center, Vicksburg, Mississippi. The pressure created in the SAVIAC experiments was recorded at 50-100 psi in open water at $30 \mathrm{~cm}$ from the discharge source. When the focusing tubes were introduced into the pipelines, the pressure increased to $300-400 \mathrm{psi}$ at $30 \mathrm{~cm}$ from the discharge source. These attributes of the pressure pulse were duplicated in both the Aqualab and field experiments. The pressure dissipates as it is forced down the inside of the pipelines.

In the experiments conducted at the Aqualab and at the Nanticoke T.G.S, the voltage was kept

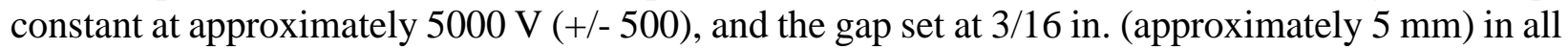
experiments. Increasing the voltage and the gap size would have increased the pressure within the pipe, but due to the nature and length of the testing vessels, a higher voltage was not required. The equipment was set to discharge at $40 \mathrm{sec}(+/-)$ in all laboratory and field experiments. This discharge frequency can be easily altered to speed up the discharge cycle or slow it down. Differences in pipeline length, diameter, and material dictate the discharge frequency. For shorter pipes, as were used in these experiments, a 40-sec discharge cycle was more than adequate to accomplish the required task. 
The speed of propagation of the pressure pulse was 5,000 fps (approximately 1,525 m/sec). The speed does not change with an increase or decrease in the voltage or gap size. By increasing the discharge frequency, greater water flows, and pipe lengths can be treated based upon the propagation speed of the pulse.

Physical attributes can also affect the energy consumption of the technology. If the discharge frequency is increased, more energy is necessary to operate the equipment. An increase in voltage requires greater power consumption. In both the laboratory and field experiments, the voltage and discharge cycles selected required approximately $0.13726 \mathrm{kWh}$. This translates to a total energy consumption of $1,224 \mathrm{kWh} / \mathrm{yr}$ when the plasma sparker discharges at 40-sec intervals at 5,000 volts. Based on a $\mathrm{kWh}$ cost of $\$ 0.05 / \mathrm{kWh}$, this translates to a total energy cost of $\$ 61.20 /$ year.

\section{Summary}

Studies performed to date support the use of pulsed power for controlling fouling by both zebra mussels and biofilm. From a proactive standpoint, control with pulsed power accomplished the following:

- The control coupons that were removed at monthly intervals from the bottom and sides of pipes had approximately 29 times more mussel recruits $\left(\right.$ mean $=10,537$ mussels $\left./ \mathrm{m}^{2}\right)$ than did the coupons from the pulsed pipes $\left(\right.$ mean $=367$ mussels $\left./ \mathrm{m}^{2}\right)$.

- $\quad$ Coupons cut from the sides and tops of each pipe at the end of the experiment showed nearly two orders of magnitude (i.e. $100 \mathrm{x}$ ) difference in recruitment between the control and pulsed pipes, with an average of 50,690 mussels $/ \mathrm{m}^{2}$ in the control pipes and 584 mussels $/ \mathrm{m}^{2}$ in the pulsed pipes.

- Measurements of shell lengths of new recruits at the end of 3 months of growth showed significantly smaller mussels in the pulsed pipes $(5.8-\mathrm{mm}$ mean shell length) than in the control pipes (6.9-mm mean shell length).

- Biofilm biomass formation was significantly reduced in pipes in the field and laboratory test tanks by at least an order of magnitude.

Reactively, control with pulsed power accomplished the following:

- Mortality/detachment of adults on rocks placed within pipes was greater in pulsed pipes than in control pipes.

- Adult zebra mussel mortality in laboratory test tanks was 14 percent in pipes placed within control tanks and 54 percent in pipes placed within the pulsed tanks.

- $\quad$ Preliminary studies using scanning electron microscopy on dead shells from pulsed tanks and control tanks to date indicate that the pressure waves affect the integrity of the shell, with approximately 75 percent more cracks in the shells from pulsed tanks than in shells from control tanks. 


\section{PROBLEMS AND ISSUES TO BE RESOLVED}

The flow rates through the pipes at Nanticoke were too slow, which caused sediment to gather on the bottom of the pipes and on the glass slides inserted for biofilm analyses. The accumulation of mud and sediments prevented an analysis of the species composition of the biofilm that did accumulate. However, while the accumulation of mud on the bottom of the pipes and on glass slides resulted in no conclusion about the effect of plasma pulses on biofilm composition, there is evidence to suggest that plasma pulses cause suspended materials to settle out of the water. This is an issue that needs to be investigated further.

While the above conclusions are valid for small-diameter $(30 \mathrm{~cm})$, short pipes $(4 \mathrm{~m} \mathrm{long})$, we are unable to extrapolate the results to predict effects in longer and wider diameter pipes. It was hoped that decay rates in zebra mussel mortality for long pipes could be predicted by examining the decay rate in mortality along a 4-m pipe. However, mortality of mussels was so complete in $4 \mathrm{~m}$ that it was not possible to extrapolate for effects in longer pipes. The efficacy of limiting biofouling in long pipes with pulsed power needs to be determined in future studies.

While the plasma pulsers operated over the 3 months with very few problems (see Appendix I) over the duration of the experiment, SEI is using the information to (1) develop an electrode made of titanium instead of stainless steel, and (2) develop a more reliable firing mechanism that would greatly reduce the incidence of repair and frequency of replacement of electrodes. The new electrode materials and mechanism will also need to be evaluated.

POINTS OF CONTACT: This technical note was written by Dr. Gerry L. Mackie, University of Guelph, Department of Zoology, Guelph, Ontario; and Messrs. Philip Lowery and Clint Cooper, Sparktec Environmental, Inc., Stoney Creek, Ontario. For additional information, contact the manager of the Zebra Mussel Research Program at the Engineer Research and Development Center, Dr. Edwin Theriot, (601-634-2678, Edwin.A.Theriot@erdc.usace.army.mil). This technical note should be cited as follows:

Mackie, G. L., Lowery, P., and Cooper, C. (2000). "Plasma pulse technology to control zebra mussel biofouling," Zebra Mussel Technical Notes Collection (ERDC TN-ZMR-2-22), U.S. Army Engineer Research and Development Center, Vicksburg, MS. www.wes.army.mil/el/elpubs/zebtnote.html 


\section{APPENDIX I \\ Sparktec Environmental Inc. Service Report for Period \\ August 25 to November 24, 1998}

\section{DATE TREATMENT \# REASON FOR SERVICE}

Aug 25

Sept 9

$1,2, \& 3$

Sept 15

$2 \& 3$

Sept 18

\section{2}

Sept 22

2

Sept 29

Oct 6

Oct 13

Oct 20

Oct 29

Nov 10

Nov 20

Nov 24
Installation completed, all units started

Scheduled electrode change

High voltage connection wire off in the submersible assembly. Wires reattached. Unit tested okay

Electrodes not re-setting properly. Changed electrode in submersible. Re-set, tested okay

Connection to the electrode in the switch burned off. Unit re-attached and tested okay

Shut down for first set of samples.

Power supply failure. Repaired, tested okay

Small capacitor failure. Replaced unit. Tested okay

Pump failure, re-primed pump. Tested okay

Jet pump failure. Replaced with new jet pump

Took second set of samples

Shut down to install rock samples

Main power off at site; Pulled pipes out of water

Final samples taken

Dismantled site and removed equipment. Returned all pipes and equipment to Guelph

NOTE: The contents of this technical note are not to be used for advertising, publication, or promotional purposes. Citation of trade names does not constitute an official endorsement or approval of the use of such products. 